\title{
Estimating the Sarety of Using Recombinant Analogues of Spidroins as Biodegradable Scaftolds for Regenerative Medicine
}

DOI: $10.17691 / \mathrm{stm} 2017.9 .1 .04$

Received November 16, 2016

R.D. Lapshin, PhD, Head of Experimental Modeling Department, Central Scientific Research Laboratory';

P.A. Loginov, Junior Researcher, Experimental Modeling Department, Central Scientific Research Laboratory'; 1.1. Belousova, PhD, Researcher, Experimental Modeling Department, Central Scientific Research Laboratory'; N.V. Zhemarina, PhD, Senior Researcher, Morphology Department, Central Scientific Research Laboratory'; N.N. Prodanets, PhD, Senior Researcher, Morphology Department, Central Scientific Research Laboratory'; T.1. Solovyova, PhD, Senior Researcher, Biochemistry Department, Central Scientific Research Laboratory'; N.A. Stchelchkova, PhD, Head of Molecular Cellular Technology Unit, Central Scientific Research Laboratory'; L.B. Snopova, DSc, Head of Morphology Department, Central Scientific Research Laboratory'; I.V. Mukhina, DSc, Professor, Head of Central Scientific Research Laboratory'; Head of the Department of Normal Physiology named after N.Y. Belenkov'; Professor, Department of Neurotechnologies, Institute of Biology and Biomedicine'; ${ }^{2}$ Head of the Center of Translational Technology2; L.I. Davydova, PhD, Senior Researcher, Laboratory of Protein Engineering; V.G. Bogush, PhD, Leading Researcher, Laboratory of Protein Engineering ${ }^{3}$

${ }^{1}$ Nizhny Novgorod State Medical Academy, 10/1 Minin and Pozharsky Square, Nizhny Novgorod, 603005, Russian Federation;

2Lobachevsky State University of Nizhni Novgorod, 23 Prospekt Gagarina, Nizhny Novgorod, 603950,

Russian Federation;

${ }^{3}$ State Research Institute for Genetics and Selection of Industrial Microorganisms, 1, $1^{\text {st }}$ Dorozhny proezd, Moscow, 117545, Russian Federation

The aim of the investigation was to study toxic properties (chronic toxicity, local irritant and sensitizing effects) of medical products Hydrogel RS and Microgel RS, intended for use in regenerative medicine as implants for replacing defects of soft and bone tissues, treatment of deep burns and for in vitro cell culturing when testing medications.

Materials and Methods. The work was carried out on outbred Wistar rats, Chinchilla rabbits, guinea pigs. There was investigated chronic toxicity, local irritant and sensitizing effects of medical products Hydrogel RS and Microgel RS (GosNIIGenetika, Russia) based on recombinant spidroin (with cutaneous and intramuscular routes of administration). While investigating chronic toxicity, there were recorded integral, hematological, biochemical indices. Local irritation was studied by pathomorphological examination of the areas of medical product introduction. Sensitization was studied using maximization method and closed epicutaneous applications.

Results. Medical products Hydrogel RS and Microgel RS were found to be relatively safe when used during 90 days, they have no irritant effect when introduced epicutaneously and intramuscularly, no sensitizing properties and can be recommended for clinical testing.

Conclusion. Medical products Hydrogel RS and Microgel RS can be recommended for clinical testing as implants for replacing defects of soft and bone tissues, treatment of deep burns and for in vitro cell culturing in testing medicines.

Key words: biodegradable matrixes; biodegradable scaffolds; recombinant spidroins; Hydrogel RS; Microgel RS.

Polymer materials of various origins are widely used in different fields: from manufacturing household articles to regenerative medicine (reconstruction of lost tissues and organs in the body) [1, 2]. The major problem of their application in regenerative therapy is the absence of biologically active materials having the entire set of necessary properties at the same time: biocompatibility, controlled biodegradability, porosity, controlled accuracy, etc.
One of the possible solutions to this problem is the use of recombinant analogues of spider dragline silk proteins, i.e. spidroins, which, apart from distinguished physical and chemical properties (a combination of high strength and elasticity, high and low temperature resistance, positive charge in the whole range of physiological $\mathrm{pH}$ values), also possess high biocompatibility, slow bioresorption and affect cells in a targeted way, for example, integrating various biologically active compounds in

For contacts: Vladimir G. Bogush, e-mail: vlbogush@mail.ru 
their structure using genetic engineering techniques, including cell adhesion and growth factors, differentiation factors $[3,4]$. These proteins are able to form various supramolecular structures in the water environment: films, hydrogels, microgels, spongia with adjustable pore size (from nano- to macro-dimensional), microcapsules, etc. $[5,6]$.

The recombinant analogue of spidroin 1, protein 1F9 [7, 8], cloned in GosNIIGenetika and generated by microbiological synthesis in Saccharomyces cerevisiae yeast cells, has been used for production of porous matrixes [9] as well as hydrogel and microgel obtained by mechanical grinding the hydrogel [10], on the basis of which medical products Hydrogel RS and Microgel RS have been developed.

It has been established that on the surface of hydrogel and microgel there are both macropores up to $500 \mu \mathrm{m}$ in diameter and micropores 2-20 $\mu \mathrm{m}$ in diameter, connected by openings, and in the relief elements there are both nano- and microstructures $100-500 \mathrm{~nm}$ and $0.5-15 \mu \mathrm{m}$ in size, respectively [11], which makes these products attractive for use as adhesive cell cultures and contributes to vascularization and innervation processes in the implantation zone.

Applying hydrogel and microgel on the surface of a burn wound in experimental animals accelerates healing as compared to traditional methods of treatment. A greater effect is observed when injecting the samples under the wound surface [11]. The study on mice, using experimental model of full-thickness skin wound imitating severe skin damage, has shown that intradermal injections of microgel suspension around the wound provide regeneration of the body's own tissues in the area of skin lesion, and also promote neurogenesis and angiogenesis [12], i.e. the injections initiate tissue formation processes in the area of local damage.

These results show that medical products Hydrogel RS and Microgel RS based on recombinant spidroin are the materials potentially suitable for use in regenerative medicine and can be highly demanded in treatment of deep burns, as implants for replacing defects of soft and bone tissue and for in vitro cell culturing when testing medications.

The aim of the investigation was to study toxic properties, chronic toxicity, local irritant and sensibilizing effects of medical products Hydrogel RS and Microgel RS.

Materials and Methods. Hydrogel samples were obtained from $3 \%$ solution of highly purified recombinant spidroin 1F9 [8], and microgel was made by mechanical grinding the hydrogel. To obtain medical products, hydrogel and microgel were placed in syringes of 1 and $2 \mathrm{ml}$, sterilized using tyndallization method (threefold repeating the processes of heating to $90^{\circ} \mathrm{C}$ and incubation at room temperature during $20 \mathrm{~h}$ ) and packed into blisters.

Toxicological studies of medical products Hydrogel RS and Microgel RS (GosNIIGenetika, Russia) were carried out on animals in accordance with GOST R ISO 10993-2009, parts 1, 2, 10 and 11 and researcher's Standard Operating Procedures developed in Central Scientific Research Laboratory of Nizhny Novgorod State Medical Academy. The basic rules of animal care and management corresponded to the regulatory standards provided in the guidebook "Guide for the Care and Use of Laboratory Animals" (ILAR publication, 1996, National Academy Press), the national standard of RF GOST 33044-2014 "Principles of Good Laboratory Practice", in sanitary and epidemiological rules SP 2.2.1.3218-14 "Sanitary and epidemiological requirements for organization, equipment and management of experimental biological clinics (vivaria)" approved by Chief State Medical Officer of the Russian Federation and dated 29 August 2014 No.51, registered by the Ministry of Justice of the Russian Federation on 31 October 2014, registration No.34547, approval agreed upon by Ethics Committee of Nizhny Novgorod State Medical Academy.

Chronic toxicity. Experiments were carried out on 240 outbred Wistar rats (120 females and 120 males) weighing $195.5 \pm 0.5 \mathrm{~g}$, which were divided into the following groups:

a) control, saline solution epicutaneously (10 females + 10 males);

b) control, saline solution intramuscularly (10 females + 10 males);

c) hydrogel RS/Microgel RS, $0.5 \mathrm{ml} / \mathrm{kg}$ epicutaneously (10 females + 10 males);

d) hydrogel RS/Microgel RS, $5 \mathrm{ml} / \mathrm{kg}$ epicutaneously (10 females + 10 males);

e) hydrogel RS/Microgel RS, $0.5 \mathrm{ml} / \mathrm{kg}$ intramuscularly (10 females + 10 males);

f) hydrogel RS/Microgel RS, $5 \mathrm{ml} / \mathrm{kg}$ intramuscularly (10 females +10 males).

Medical products Hydrogel RS and Microgel RS were introduced epicutaneously and intramuscularly, single dose. Due to slow resorption rate of the product material, it was possible to observe its daily impact on the organism during 90 days. Within the period of 90 days (no more than $10 \%$ of rat life expectancy), the changes of integral indices were recorded, there was estimated the adverse effect occurring after single introduction of the studied sample of the medical product.

The general condition of the animals was assessed by manifestations of respiratory function, physical activity, presence of convulsions, reflexes, ophthalmoscopy was carried out, there was assessed pulse, salivation, coat condition, pain reaction, muscle tone, the condition of digestive tract and skin. The animals were weighed, water and food consumption taken into account.

In addition to integral indices recorded initially and once a month after introduction of the studied products, there were recorded hematological indices (the number of erythrocytes, leucocytes, thrombocytes, hemoglobin level, ESR, white blood cell differential), biochemical indicators and enzymatic activity of rat blood serum 
(total protein, creatinine, urea, glucose, cholesterol, total lipids, total bilirubin, alkaline phosphatase, lactate dehydrogenase, aspartate and alanine aminotransferase activity, calcium, potassium, sodium), the functional condition of excretory system was assessed according to urine analysis.

Pathomorphological examination of rats was performed 90 days after the introduction and consisted of necropsy, macroscopic study, weighing the organs and calculating mass coefficients, histological study.

Local irritation. Pathomorphological examinations of the area of medical product introduction were carried out on Chinchilla rabbits $(n=24)$ by single epicutaneous application in two groups for each product $(n=12)$ :

a) control, saline solution epicutaneously (3 females + 3 males);

b) hydrogel RS/Microgel RS, $5 \mathrm{ml} / \mathrm{kg}$ epicutaneously (3 females +3 males).

To calculate irritation index, there were used observation findings obtained within 24, 48, $72 \mathrm{~h}$. Primary irritation index was calculated summing up the scores of product-induced primary irritation for each animal, including edema and erythema, in each interval of observation time and their dividing by the total number of observations (by 6, i.e. 2 for each interval of time). To ensure the objectivity of studies, primary irritation score of the control group was subtracted from primary irritation score of the studied material.

Sensitizing effect. To study delayed hypersensitivity when using medical products Hydrogel RS and Microgel RS in accordance with GOST R ISO 10993-2009, guinea pig maximization test and the method of closed epicutaneous applications (Buehler) were used on guinea pigs $(n=30)$. There were two groups of animals for each product $(n=15)$ [10]:

a) control, saline solution (5 males);

b) hydrogel RS/Microgel RS (10 males).

The dose of the medical product, introduced intracutaneously in each studied area, was $0.1 \mathrm{ml}$. To make an application, a moisture-retentive gauze pad $\left(8 \mathrm{~cm}^{2}\right)$ was saturated with the sample under study, applied to clipped skin areas and fixed with occlusive dressing around the animal body. After $24 \mathrm{~h}$, the dressing and the samples were taken off and the condition of the studied areas was assessed for the presence of erythema and edema according to Magnusson and Kligman classification.

Seven days after the intracutaneous induction phase, the studied material was applied epicutaneously on the injection sites (the intrascapular area of each animal) using $8 \mathrm{~cm}^{2}$ pieces of impregnated gauze. Occlusive dressing was applied. The dressing was taken off in $48 \pm 2 \mathrm{~h}$. Fourteen days ( \pm 1 day) after the local induction phase was completed, all experimental and control animals were challenged by the tested materials. For this, applications of the studied material were made on the intact areas of each animal side skin, a hygroscopic gauze pad being applied for $24 \mathrm{~h}$. The degree of skin reaction, including erythema and edema, was estimated and described (according to Magnusson and Kligman) for each area and in each observation time interval.

Methods of statistical data analysis. The data obtained were processed using software package Statistica 5.5. To compare the samples $(n=20)$ in case of normal distribution of populations, parametric Student's t-test was used for paired samples (dependent samples) or unpaired samples (independent). Non-parametric criteria were used in case of significant deviations of sign distribution from the normal law and with small samples $(n \leq 10)$ : Wilcoxon test for two dependent samples and Mann-Whitney U-test in case of two independent samples. When comparing more than two groups, the Kruskal-Wallis test was used. The differences between groups were considered statistically significant at the level of $p<0.05$.

Results and Discussion. Studies performed on white outbred rats have shown that with a single epicutaneous application and a single intramuscular introduction of subacute doses of 0.5 and $5.0 \mathrm{ml} / \mathrm{kg}$, medical products Hydrogel RS and Microgel RS are safe substances. They have no irritant effect when introduced epicutaneously and intramuscularly, no sensitizing properties and can be recommended for clinical testing. There were no deaths of the animals, no changes in their general state in relation to respiratory function, physical activity, the presence of convulsions, reflexes, according to the findings of ophthalmoscopy, assessment of pulse, salivation, coat condition, pain reaction, muscle tone, the condition of digestive tract and skin. No difference in animal weight growth was found after introduction of the studied and control medical products (Table 1).

No difference in biochemical and morphological parameters of blood and urine, mass coefficients of organs was found in the animals of the control group when medical products Hydrogel RS and Microgel RS were applied epicutaneously on a once-only basis and introduced intramuscularly as a single injection in subacute doses (Table 2).

When local irritation was studied in the process of applying medical products Hydrogel RS and Microgel $\mathrm{RS}$ to the skin of rabbits, no irritant effect was revealed. No signs of erythema, edema or other irritation signs were noted during the period of observation.

As a result of studies conducted on guinea pigs, it was found that medical products Hydrogel RS and Microgel RS have no sensitizing properties. Guinea pig maximization test revealed no skin reaction, including erythema and edema, on the tested areas after the intracutaneous induction phase, which corresponds to 0 scores, according to Magnusson and Kligman classification. After the animals were challenged by the tested material on completion of the induction phase of the investigation, no skin reaction (including erythema and edema) was found, which corresponds to 0 scores, according to Magnusson and Kligman classification (Table 3). 
Table 1

The impact of medical products Hydrogel RS and Microgel RS on body weight (g) during 90 days, with a single epicutaneous application and a single intramuscular injection given to white outbred rats (M $\pm S E M)$

\begin{tabular}{|c|c|c|c|c|c|c|}
\hline \multirow{3}{*}{$\begin{array}{l}\text { Investigation } \\
\text { stage }\end{array}$} & \multirow{2}{*}{\multicolumn{2}{|c|}{ Investigation stage }} & \multirow{2}{*}{\multicolumn{2}{|c|}{$\begin{array}{c}\text { Hydrogel RS } \\
5 \mathrm{ml} / \mathrm{kg}\end{array}$}} & \multirow{2}{*}{\multicolumn{2}{|c|}{$\begin{array}{c}\text { Microgel RS } \\
5 \mathrm{ml} / \mathrm{kg}\end{array}$}} \\
\hline & & & & & & \\
\hline & Male $(n=10)$ & Female $(n=10)$ & Male $(n=10)$ & Female $(n=10)$ & Male $(n=10)$ & Female $(n=10)$ \\
\hline \multicolumn{7}{|c|}{ Single epicutaneous application } \\
\hline Baseline indices & $209.30 \pm 1.67$ & $199.60 \pm 2.16$ & $211.00 \pm 2.19$ & $198.00 \pm 1.93$ & $209.00 \pm 1.89$ & $201.00 \pm 2.02$ \\
\hline 7 days & $227.90 \pm 2.30$ & $218.50 \pm 0.69$ & $230.90 \pm 2.46$ & $217.70 \pm 1.43$ & $232.40 \pm 1.52$ & $214.10 \pm 1.21$ \\
\hline 14 days & $251.20 \pm 1.66$ & $226.30 \pm 1.16$ & $253.40 \pm 1.51$ & $226.40 \pm 1.24$ & $248.40 \pm 1.48$ & $227.30 \pm 0.70$ \\
\hline 21 days & $270.00 \pm 2.14$ & $236.60 \pm 1.19$ & $267.40 \pm 1.50$ & $235.30 \pm 1.48$ & $271.40 \pm 1.81$ & $235.60 \pm 1.14$ \\
\hline 1 month & $288.20 \pm 1.58$ & $245.40 \pm 0.99$ & $286.00 \pm 2.28$ & $246.40 \pm 1.39$ & $289.40 \pm 2.03$ & $244.90 \pm 1.41$ \\
\hline 2 months & $341.00 \pm 2.13$ & $290.00 \pm 2.57$ & $341.10 \pm 2.17$ & $293.60 \pm 3.66$ & $343.30 \pm 2.56$ & $292.60 \pm 2.61$ \\
\hline 3 months & $375.40 \pm 4.16$ & $328.90 \pm 4.14$ & $371.70 \pm 2.60$ & $326.30 \pm 2.29$ & $375.10 \pm 4.04$ & $330.00 \pm 3.34$ \\
\hline \multicolumn{7}{|c|}{ Single intramuscular injection } \\
\hline Baseline indices & $207.90 \pm 1.92$ & $200.70 \pm 1.90$ & $210.00 \pm 2.26$ & $200.40 \pm 1.87$ & $211.40 \pm 1.73$ & $200.60 \pm 2.20$ \\
\hline 7 days & $227.20 \pm 1.66$ & $214.80 \pm 1.24$ & $226.60 \pm 2.13$ & $216.10 \pm 1.02$ & $230.40 \pm 2.05$ & $215.60 \pm 1.32$ \\
\hline 14 days & $245.80 \pm 1.92$ & $224.80 \pm 0.71$ & $252.30 \pm 1.65$ & $225.30 \pm 1.41$ & $246.90 \pm 1.83$ & $227.00 \pm 0.77$ \\
\hline 21 days & $265.40 \pm 1.71$ & $234.20 \pm 0.93$ & $270.70 \pm 2.20$ & $236.60 \pm 1.39$ & $270.40 \pm 2.19$ & $235.10 \pm 1.51$ \\
\hline 1 month & $292.60 \pm 2.03$ & $246.50 \pm 1.22$ & $287.20 \pm 1.96$ & $245.10 \pm 1.35$ & $289.60 \pm 1.82$ & $248.30 \pm 1.10$ \\
\hline 2 months & $342.10 \pm 2.39$ & $290.20 \pm 2.81$ & $344.60 \pm 2.19$ & $297.00 \pm 2.88$ & $343.20 \pm 2.80$ & $291.80 \pm 2.76$ \\
\hline 3 months & $377.90 \pm 1.93$ & $331.00 \pm 1.24$ & $374.60 \pm 3.05$ & $331.60 \pm 3.74$ & $377.90 \pm 2.82$ & $332.00 \pm 2.61$ \\
\hline
\end{tabular}

Table 2

The impact of medical products Hydrogel RS and Microgel RS on mass coefficients of organs within 90 days after a single epicutaneous application and a single intramuscular injection given to white outbred rats (M \pm SEM)

\begin{tabular}{|c|c|c|c|c|c|c|}
\hline \multirow{3}{*}{ Organs } & \multirow{2}{*}{\multicolumn{2}{|c|}{ Control }} & \multirow{2}{*}{\multicolumn{2}{|c|}{$\begin{array}{c}\text { Hydrogel RS } \\
5 \mathrm{ml} / \mathrm{kg}\end{array}$}} & \multirow{2}{*}{\multicolumn{2}{|c|}{$\begin{array}{c}\text { Microgel RS } \\
5 \mathrm{ml} / \mathrm{kg}\end{array}$}} \\
\hline & & & & & & \\
\hline & Male $(n=10)$ & Female $(n=10)$ & Male $(n=10)$ & Female $(n=10)$ & Male $(n=10)$ & Female $(n=10)$ \\
\hline \multicolumn{7}{|c|}{ Single epicutaneous application } \\
\hline Heart & $2.72 \pm 0.05$ & $3.08 \pm 0.12$ & $2.12 \pm 0.09$ & $2.94 \pm 0.13$ & $2.58 \pm 0.11$ & $2.98 \pm 0.07$ \\
\hline Lungs & $4.82 \pm 0.11$ & $5.62 \pm 0.13$ & $4.26 \pm 0.17$ & $5.50 \pm 0.10$ & $4.74 \pm 0.14$ & $5.48 \pm 0.17$ \\
\hline Thymus & $0.75 \pm 0.01$ & $0.92 \pm 0.05$ & $0.72 \pm 0.05$ & $0.90 \pm 0.05$ & $0.75 \pm 0.02$ & $0.97 \pm 0.02$ \\
\hline Liver & $27.67 \pm 0.83$ & $30.02 \pm 1.31$ & $26.91 \pm 1.04$ & $30.15 \pm 0.94$ & $27.34 \pm 0.85$ & $30.91 \pm 0.91$ \\
\hline Spleen & $3.08 \pm 0.07$ & $3.10 \pm 0.10$ & $3.03 \pm 0.18$ & $3.20 \pm 0.10$ & $2.94 \pm 0.15$ & $3.29 \pm 0.14$ \\
\hline Kidneys & $4.59 \pm 0.13$ & $5.33 \pm 0.11$ & $4.46 \pm 0.09$ & $5.34 \pm 0.12$ & $4.68 \pm 0.15$ & $5.21 \pm 0.12$ \\
\hline Adrenal glands & $0.18 \pm 0.01$ & $0.20 \pm 0.01$ & $0.17 \pm 0.01$ & $0.19 \pm 0.01$ & $0.18 \pm 0.01$ & $0.21 \pm 0.01$ \\
\hline Brain & $5.21 \pm 0.08$ & $5.36 \pm 0.09$ & $5.18 \pm 0.06$ & $5.30 \pm 0.10$ & $5.20 \pm 0.10$ & $5.29 \pm 0.07$ \\
\hline Seminal glands/ovaries & $8.27 \pm 0.18$ & $0.53 \pm 0.02$ & $7.94 \pm 0.44$ & $0.52 \pm 0.03$ & $7.93 \pm 0.22$ & $0.54 \pm 0.02$ \\
\hline \multicolumn{7}{|c|}{ Single intramuscular injection } \\
\hline Heart & $2.63 \pm 0.09$ & $3.05 \pm 0.08$ & $2.62 \pm 0.09$ & $3.08 \pm 0.16$ & $2.61 \pm 0.05$ & $2.99 \pm 0.07$ \\
\hline Lungs & $4.77 \pm 0.20$ & $5.13 \pm 0.18$ & $4.90 \pm 0.14$ & $5.21 \pm 0.24$ & $4.61 \pm 0.14$ & $5.03 \pm 0.12$ \\
\hline Thymus & $0.78 \pm 0.04$ & $0.91 \pm 0.05$ & $0.81 \pm 0.04$ & $0.94 \pm 0.03$ & $0.82 \pm 0.03$ & $0.89 \pm 0.03$ \\
\hline Liver & $26.02 \pm 1.19$ & $29.69 \pm 0.73$ & $27.37 \pm 1.18$ & $31.83 \pm 1.85$ & $26.69 \pm 1.01$ & $29.71 \pm 1.05$ \\
\hline Spleen & $2.81 \pm 0.10$ & $3.10 \pm 0.12$ & $2.93 \pm 0.09$ & $3.22 \pm 0.25$ & $2.76 \pm 0.10$ & $3.05 \pm 0.09$ \\
\hline Kidneys & $4.45 \pm 0.06$ & $5.15 \pm 0.11$ & $4.40 \pm 0.18$ & $5.28 \pm 0.22$ & $4.42 \pm 0.08$ & $5.17 \pm 0.08$ \\
\hline Adrenal glands & $0.17 \pm 0.01$ & $0.17 \pm 0.01$ & $0.17 \pm 0.01$ & $0.19 \pm 0.01$ & $0.17 \pm 0.01$ & $0.17 \pm 0.01$ \\
\hline Brain & $5.17 \pm 0.07$ & $5.20 \pm 0.07$ & $5.01 \pm 0.12$ & $5.27 \pm 0.12$ & $5.03 \pm 0.12$ & $5.19 \pm 0.09$ \\
\hline Seminal glands/ovaries & $8.01 \pm 0.14$ & $0.53 \pm 0.01$ & $8.04 \pm 0.27$ & $0.55 \pm 0.02$ & $8.09 \pm 0.29$ & $0.52 \pm 0.01$ \\
\hline
\end{tabular}


Table 3

The results of guinea pig maximization test performed to study sensitizing effect of medical products Hydrogel RS and Microgel RS (scores)

\begin{tabular}{lccc}
\hline \multicolumn{1}{c}{ Number of scores } & Control & $\begin{array}{c}\text { Hydrogel } \\
\text { RS }\end{array}$ & $\begin{array}{c}\text { Microgel } \\
\text { RS }\end{array}$ \\
\hline Intracutaneous induction phase & 0 & 0 & 0 \\
Challenge phase & 0 & 0 & 0 \\
\hline
\end{tabular}

$\mathrm{N}$ o t e. Observation time interval $-24 \mathrm{~h}$.

Thus, medical products Hydrogel RS and Microgel RS are safe agents when used during 90 days, according to the data resulting from evaluation of integral parameters of the functional state of the rat body (appearance, reflexes, biochemical and morphological indices of blood and urine). They have no irritant effect when introduced epicutaneously and intramuscularly as the experiments with rabbits show, display no sensitizing properties in the experiments with guinea pigs.

Conclusion. Medical products Hydrogel RS and Microgel RS (GosNIIGenetika, Russia) can be recommended for clinical testing as implants for replacing defects of soft and bone tissue, treatment of deep burns and for in vitro cell culturing in testing medicines.

Study Funding. This work was supported by the Ministry of Education and Science of the Russian Federation (the grant agreement No.14.579.21.0017 dated 05.06.2014, unique identifier of applied research RFMEFI57914X0017).

Conflict of Interests. The authors have no conflict of interests to disclose.

\section{References}

1. Girotti A., Orbanic D., Ibáñez-Fonseca A., GonzalezObeso C., Rodríguez-Cabello J.C. Recombinant technology in the development of materials and systems for soft-tissue repair. Adv Healthc Mater 2015; 4(16): 2423-2455, https://doi. org/10.1002/adhm.201500152.

2. Carletti E., Motta A., Migliaresi C. Scaffolds for tissue engineering and 3D cell culture. Methods Mol Biol 2011; 695: 17-39, https://doi.org/10.1007/978-1-60761-984-0_2.

3. Kluge J.A., Rabotyagova O., Leisk G.G., Kaplan D.L. Spider silks and their applications. Trends Biotechnol 2008; 26(5): 244-251, https://doi.org/10.1016/j.tibtech.2008.02.006.
4. Spiess K., Lammel A., Scheibel T. Recombinant spider silk proteins for applications in biomaterials. Macromol Biosci 2010; 10(9): 998-1007, https://doi.org/10.1002/ mabi.201000071.

5. Schacht K., Jüngst T., Schweinlin M., Ewald A., Groll J., Scheibel T. Biofabrication of cell-loaded 3D spider silk constructs. Angew Chem Int Ed Engl 2015; 54(9): 2816-2820, https://doi.org/10.1002/anie.201409846.

6. Humenik M., Smith A.M., Scheibel T. Recombinant spider silks - biopolymers with potential for future applications. Polymers 2011; 3(4): 640-661, https://doi.org/10.3390/ polym3010640.

7. Bogush V.G., Sokolova O.S., Davydova L.I., Klinov D.V., Sidoruk K.V., Esipova N.G., Neretina T.V., Orchanskyi I.A., Makeev V.Y., Tumanyan V.G., Shaitan K.V., Debabov V.G., Kirpichnikov M.P. A novel model system for design of biomaterials based on recombinant analogs of spider silk proteins. J Neuroimmune Pharmacol 2008; 4(1): 17-27, https://doi.org/10.1007/s11481-008-9129-z.

8. Bogush V.G., Davydova L.I., Moisenovich M.M., Sidoruk K.V., Arkhipova A.Yu., Kozlov D.G., Agapov I.I., Kirpichnikov M.P., Debabov V.G. Characterization of biodegradable cell micro and macro carriers based on recombinant spidroin. Appl Biochem Microbiol 2014; 50(8): 780-788, https://doi.org/10.1134/s000368381408002x.

9. Moisenovich M.M., Pustovalova O., Shackelford J., Vasiljeva T.V., Druzhinina T.V., Kamenchuk Y.A., Guzeev V.V., Sokolova O.S., Bogush V.G., Debabov V.G., Kirpichnikov M.P., Agapov I.I. Tissue regeneration in vivo within recombinant spidroin 1 scaffolds. Biomaterials 2012; 33(15): 3887-3898, https://doi.org/10.1016/j.biomaterials.2012.02.013.

10. GOST R ISO 10993-10-2009. Izdeliya meditsinskie. Otsenka biologicheskogo deystviya meditsinskikh izdeliy. Chast' 10. Issledovaniya razdrazhayushchego i sensibiliziruyushchego deystviya [GOST R ISO 10993-10-2009. Medical devices. Biological evaluation of medical devices. Part 10. Tests for irritation and delayed-type hypersensitivity]. Moscow: Standartinform; 2010.

11. Moisenovich M.M., Malyuchenko N.V., Arkhipova A.Y., Kotlyarova M.S., Davydova L.I., Goncharenko A.V., Agapova O.I., Drutskaya M.S., Bogush V.G., Agapov I.I., Debabov V.G., Kirpichnikov M.P. Novel 3D-microcarriers from recombinant spidroin for regenerative medicine. Dokl Biochem Biophys 2015; 463(1): 232-235, https://doi.org/10.1134/ s1607672915040109.

12. Moisenovich M.M., Malyuchenko N.V., Arkhipova A.Y., Goncharenko A.V., Kotlyarova M.S., Davydova L.I., Vasil'eva T.V., Bogush V.G., Agapov I.I., Debabov V.G., Kirpichnikov M.P. Recombinant 1F9 spidroin microgels for murine full-thickness wound repairing. Dokl Biochem Biophys 2016; 466(1): 9-12, https://doi.org/10.1134/ s1607672916010038. 